\title{
The Concept of Research University: The Implementation in the Context of Malaysian University System
}

\author{
Nasiibah Ramli ${ }^{1}$, Zinatul A. Zainol ${ }^{1}$, Junaidi Abdul Aziz ${ }^{2}$, Hasani Mohd. Ali ${ }^{1}$, Jady Hassim ${ }^{1}$, Wan Mohd. Hirwani \\ Wan Hussein $^{3}$, Ruzian Markom ${ }^{1}$, Wan Siti Adibah Wan Dahalan ${ }^{1} \&$ Noor Inayah Yaakob ${ }^{4}$ \\ ${ }^{1}$ Faculty of Law, Universiti Kebangsaan Malaysia, Malaysia \\ ${ }^{2}$ Faculty of Electrical Engineering, Universiti Teknologi Malaysia, Malaysia \\ ${ }^{3}$ Graduate School of Business, Universiti Kebangsaan Malaysia, Malaysia \\ ${ }^{4}$ Faculty of Business and Management, Universiti Kebangsaan Malaysia, Malaysia \\ Correspondence: Nasiibah Ramli, Faculty of Law, Universiti Kebangsaan Malaysia, Malaysia. E-mail: \\ ramlinasiibah@gmail.com
}

Received: February 4, 2013 Accepted: March 19, 2013 Online Published: April 27, 2013

doi:10.5539/ass.v9n5p307 URL: http://dx.doi.org/10.5539/ass.v9n5p307

\begin{abstract}
'Innovate or perish'. Universities in this age have evolved far beyond the traditional settings where university was an institution for disseminating knowledge, but today university has been running the role of country's innovation excellence where it has become a place for disseminating and producing knowledge as well as commercializing their research output which contributed largely to the country's economic development. Thus this paper highlight the development of research university system in Malaysia which is still at infancy stage compared to RU in the United States and United Kingdom and analyse it's policy and management procedure so that it can become a direction to other countries which are trying to develop their research and innovation strategies.
\end{abstract}

Keywords: research university, Malaysian university system, history of university

\section{Introduction}

Research Universities (RU) are on the leading edge of innovation, scholarship and solution that contribute to the developed countries' economy, security and well being (Association of American Universities, 1900). The concept of RU was dated back to the $19^{\text {th }}$ century and had since been adopted by developed countries as a hub for teaching, research and innovation excellence (Atkinson \& Blanpied, 2008).

Malaysia as a successful developing country has taken big step to boost the achievement of the local public universities by introducing the status of RU and five public universities have successfully been titled as RU. 4 public universities in Malaysia were given RU status by the Malaysian government in 2006. These universities are Universiti Malaya, Universiti Kebangsaan Malaysia, Universiti Sains Malaysia and Universiti Putra Malaysia. While in the year 2010 another public university has been appointed as research university that is Universiti Teknologi Malaysia. Being RU, these universities have been directed to upgrade research and development activities as well as commercialization (Ministry of Higher Education Malaysia 2010). This development is seen as a catalyst to trigger healthy competitive nature within the public universities and it is hoped that this development will increase quality and quantity of countries invention and innovation.

Thus, this paper discusses the history of RU in order to understand the concept of RU and later on the key issues on pros and cons of RU are analysed. Then Malaysian higher education system is highlighted followed by analysis on the policies and managerial procedures adopted by the Malaysian Ministry of Higher Education. Later there will be suggestion on steps that need to be taken in order to improve RU system in Malaysia so that Malaysian experience could be used as guide by other counterpart countries.

\section{A Short History of the Concept of RU}

A simple definition of RU is 'An institution devoted mainly to research and graduate studies' (Steffensen, 2000). (Morphew, 2003) in the Encyclopedia of Education defines RUs as "postsecondary institutions that devote a large portion of their mission, resources, and focus to graduate education and research." While according to 
(Atkinson \& Blanpied, 2008) RU refers to university with dual mission that is transmission of knowledge and production of new knowledge.

Thus from the above definitions, $\mathrm{RU}$ is an expansion of the traditional university which is merely a teaching institution (David, (1992). Historically, RU was first established by the German University in the $19^{\text {th }}$ century (Lehrer, 2009). During their early establishment, production of knowledge were focused in the area of humanities or more particularly translation of Greek and Latin text (Atkinson \& Blanpied, 2008). It was only in the 1826 that a German Chemist Justus Liebig at Giessen established the first scientific laboratory which was devoted to dual mission of teaching and research (David, 1992). This development gave great contribution to the acceleration of German industry (Atkinson \& Blanpied, 2008). German university of the $19^{\text {th }}$ century is considered a success model and thus duplicated by US and many other countries.

However, it should be noted that although German model of research university, which promoted the principle of unity of research and study has been adopted by many other countries, some countries however followed the German model without giving up their traditional university framework (David, 1992). This can be seen from the French application where research function remain separated and did not integrate with the university teaching. While the British system put greater emphasis on teaching and study compared to the German model and did not completely followed the German model (David, 1992).

Later on in the 1900, efficacy of the German model of research university began to lose its appeal due to the new development in science field such as bacteriology and genetics (David, 1992). This new fields required an elaborate and organized laboratories with complex machinery which is unsuitable to be incorporated within the traditional university where professors pursue their own research agenda and share their findings with their students and publics. This difficulty has resulted to the establishment of private research institutes outside the realm of the university.

However the inconsistency of the university as a place for advanced research has been ruled out through the emergence of new model of research university introduced in the United States. According to the US model of research university, graduate schools are established to accommodate any fields even if they did not fit the existence disciplines taught at the university (David, 1992). This will surely eliminate the difficulties in harmonising the advance research function with the traditional teaching and study function of the university. Besides that the emergence of the idea that the government should held responsibility to support research undertaken by the university has also contributed to the success of the research university model (Atkinson and Blanpied, 2008). This can be seen from the largest organized research project handled by the research university which was the Manhattan Project. This research was conducted to develop the first nuclear weapon and this project was handled by the University of California (Atkinson \& Blanpied, 2008).

The new US research university model has proven to be a huge success and other countries started to duplicate the graduate school model. This phenomenon also contributed to the German research university downfall. Besides that, there was also fact that after 1945 emerged a new government policy that national universities must submit to the centralized federal rules and regulations (Lehrer, 2009). Although there is federal harmonization of German universities, expenditures for each and every universities were still made by the individual states which was insufficient to pursue new research projects (Tuffs, 2006).

Thus the new policy has caused the German universities to became uniformed institutions where talents are distributed equally between the universities, offering equal salary and working condition for the professors (Lehrer, 2009). This change of higher educational policy had affected university research badly since it was difficult to have research foci and the number of research and patent filed by the German universities decreased dramatically (Lehrer, 2009). Besides that, there was also fact that R\&D activities were moved outside the realm of the RU to the private research institutes (Tuffs, 2006) and (Lehrer, 2009). Thus university role to produce new knowledge had been taken over by privately funded research institutions such as Max Planck, Helmholtz and Fraunhofer societies (Tuffs, 2006) and (Lehrer, 2009). All these changes had caused decline of the German universities (Lehrer, 2009) and (Tuffs, 2006).

However, recently there has been changes within the German university system where in 2004 German universities have to compete for elite universities status in order to receive additional fund of US\$2.3 billion over 5 years (Tuffs, 2006). This competition is aimed to raise German's international competitiveness in innovation (Tuffs, 2006). Thus it is accepted that German universities before 1914 or pre World War II is considered leading model of teaching and research and at the same time with the decline, US universities started to flourished after 1940 and they have been considered to be at the forefront with a successful research university model (E. Shils 1992). 
It should be noted that until recently the top universities in the world are monopolized by the US and UK universities. The most recent 2009 ranking of Times Higher Education Supplements (THES) has placed 13 US research universities in top 20 universities in the world and 8 German universities in the highest 200 universities in the world with the top one at rank 55 that is Technical University of Munich (Times Higher Education Supplements, 2009). This clearly shows that US RUs are still the leading RU in the world although UK universities might be the closest rival based on THES.

The first US RU established is the John Hopkins University (JHU) in 1876 and the first president of JHU Daniel Coit Gilman in his speech stated the aim and mission of JHU (John Hopkin University) :

"The encouragement of research....and the advancement of individual scholars, who by their excellence will advance the science they pursue, and the society where they dwell." JHU was modeled after the German traditions and structure that is graduate seminar and academic freedom which was later on followed by other US

universities (Morphew, 2003). Besides that US model of RU also adopted some functions from the English university such as a comprehensive undergraduate curriculum with a residential component (Morphew, 2003).

There are about 150 research universities in US including Harvard University, MIT, Yale, Universities of Michigan and many others (Crow \& Silver, 2008). Traditionally what all these universities have in common is an emphasis on graduate education and research and they offer advanced degrees up to doctorate level (Atkinson \& Blanpied, 2008). Faculty members of US RU are expected to devote a larger amount of their time in research where the underlying principal is researchers first and teachers second (Morphew, 2003).

However, the modern US RUs have expanded in their mission and practice where now they are seen as complex organizations with variety of campuses, research centres, institutes and programs for various students groups (Crow \& Silver, 2008). Establishment of research park within RU also has become a normal practice where RU and industry engage in technology transfer for commercialization (Link \& Scott, 2007).

In defining modern US RU, the phrase "multiversity", "community of communities" and "organized anarchies" have been used by several authors in reference to US RU. The reason being is that US RU is seen as an organization striving to achieve multiple goals which has resulted in multiple communities with different interest and at times it seems like there is no leaders and rules governing the organization (Morphew, 2003). Thus, from the above discussions it appears that US RU is an independent organization with absolute autonomy to direct the focus of research and direction of the university. This US RU model has been adopted by many countries to be applied to their local universities.

\section{Key Issues about the Pros and Cons of RU}

Research university has been considered as a tool to achieve countries prosperities through knowledge based economy or known as k-economy. University which is a place for study and dissemination of knowledge is considered as the fastest and cheapest way in developing a strong k-economy of a country. The fact that most of the countries expertises are gathered within the university atmosphere is also another factor contributed to the establishment of research universities by many developed and developing countries.

Establishment of research university also has inculcate competitive nature between the research university to obtain external funding and thus it will guarantee the quality of the research outcome. This trait can be seen from the US research university culture where the competitive nature of the research universities are said to be contributing factors to the success of their research university. (Atkinson \& Blanpied, 2008)

Besides that, the continuance of the research university will later on given rise to a new model of university that is entrepreneurial university which has become very popular in the recent years. Through entrepreneurial university, management of the university will became an independent body and they can generate their own income without having to rely on the government sources.

Although US model of research university has received international acknowledgement and proven to be a huge success, there are still few issues that has to be taken into account. The first issue is regarding the fact that a large number of students in the higher education institutions who are not interested in research and their interest are only in acquiring specific professional skills. Therefore the task of performing research rest on the shoulder of the teachers who have been burdened with massive teaching workload and at the same time they have to provide some of their time for research activities. Not to mention that they are also expected to publish articles, books and secure research grants either from internal or external sources. This issue has provoked some criticism to the research university model where they are said to be biting off more than they can chew.

However, this issue can be solved through a policy introduced by the research university where lecturers are 
given options either to embark in $70 \%$ teaching and 30\% research or they can commit their time to $70 \%$ research and 30\% teaching and in this case they will be given limited workload for teaching. Second issue is that, other countries have yet to achieve similar success experienced by the US universities. Although many countries have adopted US RU model, there are still no similar success achieved by them (Kenney \& Patton, 2009; 2011); (Atkinson \& Blanpied, 2008) and (Stephen, 2010). Many authors have pointed out that, US RU model works well in the US background set up and other countries should mold it according to their own background and not by total adoption (Kenney \& Patton, 2009, 2011); (Stephen, 2010) and (Atkinson \& Blanpied). Therefore analysis on Malaysian RU is done in order to determine whether its obejective has been achieved or otherwise.

\section{The University Research System in Malaysia}

Malaysian system of higher education has taken its root from the British system of higher education during the British colonial rule. Thus it is not surprising that the British higher education system was replicated to large extent in Malaysia and formed the basis of the Malaysian higher education system (Selvaratnam, 1985).

The first establishment of higher education institutions before Malaysian independence in 1957 was King Edward VII College of Medicine in 1921 and later on Raffles College in 1928. Then on the 8 October 1949 these two higher education institutions were amalgamated and formed University of Malaya which was situated in Singapore (www.um.edu.my). However after Malaysian independence, through the force of new legislation, two autonomous division of University Malaya was established in Kuala Lumpur and Singapore (Selvaratnam, 1985).

Later on, after the formation of the Federation of Malaya, both new government, Malaysia and Singapore decided to establish their own national university. Thus Kuala Lumpur division of University Malaya became the sole University of Malaya while the division in Singapore was amalgamated with the Nanyang University and became National University of Singapore (NUS) (Selvaratnam, 1985).

University of Malaya then expand rapidly and due to high demand for places in the higher education institutions, other universities are established in Malaysia and among the oldest are University Penang established in 1969 or now known as University Sains Malaysia and National University of Malaysia or known as University Kebangsaan Malaysia was established in the following year. Then in the year 1971 and 1972 Universiti Pertanian Malaysia (Agricultural University of Malaysia) and Universiti Teknologi Malaysia (University Technology Malaysia) were established as a result from lower institution upgrade to university status (Selvaratnam, 1985).

Table 1. Statistic of tertiary education institutions in Malaysia is shown in the table below

\begin{tabular}{llll}
\hline Institution & 2000 & 2005 & 2007 \\
\hline Public University & 11 & 11 & 20 \\
Private University & 5 & 11 & 21 \\
University College & 0 & 17 & 25 \\
College & $\mathrm{n} / \mathrm{a}$ & $\mathrm{n} / \mathrm{a}$ & 390 \\
Polytechnic & 14 & 25 & 27 \\
Community College & $\mathrm{n} / \mathrm{a}$ & $\mathrm{n} / \mathrm{a}$ & 59 \\
\hline
\end{tabular}

Source: Malairaja and Zawdie, Science Parks and University-Industry Collaboration in Malaysia, 2008 and Ministry of Higher Education Malaysia official website

Appointment of four public universities as research university (RU) on the 11th October 2006 is a good step taken in order to boost up the number of research and innovation in Malaysia. The four RUs are Universiti Malaya, Universiti Kebangsaan Malaysia, Universiti Putera Malaysia and Universiti Sains Malaysia. While on the June 10th 2010 Universiti Teknologi Malaysia has been announced to join the group of Malaysian Research University.

Thus Malaysian RU is defined as a public university which has been recognised as a university which focused more on research activities and education based on research and development (R\&D) (Malaysian Ministry of Higher Education, MOHE).

Establishment of RU is seen as a trigger to increase innovation in Malaysia and lead a knowledge-based economy. RU also aims to increase intake of postgraduate and postdoctoral, to increase total of $\mathrm{PhD}$ holders 
among the lecturers and also to increase international students intake and to achieve high ranking among the established universities in the world (Malaysian Ministry of Higher Education).

The Strategic Plan of National Higher Education, envision that at least 3 institutes of higher education will be listed among 100 best universities in the world and 1 university among 50 best universities in the Times Higher Education Supplement (THES) ranking before year 2020 (Malaysian Ministry of Higher Education). Thus in order to ensure the success of RU, Research University Special Fund has been established by the Ministry of Higher Education where over RM100 million has been distributed over between year 2007 and 2008 (NSUNT 2009).

Besides that, government has also taken steps to give greater level of autonomy to the public universities by amending the Universities and University Colleges Act where the University Council was replaced by the respective university's Board of Directors (BOD) (Ministry of Higher Education Malaysia 2010). This will give the university more power in decision making in order to decide the university direction to a successful RU.

It should be noted that, the Malaysian RUs are chosen and decided by the Research University Evaluation Committee after a public university has achieved $75 \%$ marks from the self-assessment (Ministry of Higher Education Malaysia). Below are tables of the number of students in the Malaysian public university in the year 1985 and Malaysian Research University in the year 2010.

Table 2. Number of students at Malaysian university in 1985

\begin{tabular}{ll}
\hline University & Year 1985 \\
\hline Universiti Malaya & 9890 \\
Universiti Sains Malaysia & 8862 \\
Universiti Kebangsaan Malaysia & 10220 \\
Universiti Putra Malaysia & 8412 \\
Universiti Teknologi Malaysia & 7472 \\
\hline
\end{tabular}

Source: Selvaratnam, The Higher Education System in Malaysia: Metropolitan, Cross-national, Peripheral or National?, 1985

Table 3. Number of students at Malaysian research university in year 2010

\begin{tabular}{|c|c|c|c|c|}
\hline University & $\begin{array}{l}\text { Local } \\
\text { Undergtraduate }\end{array}$ & $\begin{array}{l}\text { International } \\
\text { Undergraduate }\end{array}$ & $\begin{array}{l}\text { Local } \\
\text { Postgraduate }\end{array}$ & $\begin{array}{l}\text { International } \\
\text { Postgraduate }\end{array}$ \\
\hline Universiti Malaya & 13133 & 857 & 9221 & 2263 \\
\hline Universiti Putra Malaysia & 18878 & 86 & 10283 & 2794 \\
\hline Universiti Sains Malaysia & 17833 & 436 & 6180 & 2561 \\
\hline $\begin{array}{l}\text { Universiti } \quad \text { Kebangsaan } \\
\text { Malaysia }\end{array}$ & 14357 & - & 9656 & $2477^{*}$ \\
\hline $\begin{array}{l}\text { Universiti } \\
\text { Malaysia }\end{array}$ & 15232 & 699 & 6239 & 1895 \\
\hline
\end{tabular}

Source: Taken from each university official website as of $8^{\text {th }}$ November 2012

* total number of international students in UKM including undergraduate and postgraduate.

Table 4. Number of academic staff for research university

\begin{tabular}{lll}
\hline University & Domestic Academic Staff & International Academic Staff \\
\hline Universiti Malaya & 2613 & 590 \\
Universiti Putra Malaysia & 2902 & 97 \\
Universiti Sains Malaysia & 1522 & 134 \\
Universiti Kebangsaan Malaysia & 2248 & - \\
Universiti Teknologi Malaysia & 1874 & 109 \\
\hline
\end{tabular}

Source: Taken from each university official website as of $8^{\text {th }}$ November 2012 
The above tables show the growth of Malaysian Higher Education Institustions.

\section{The Adoptions of Policies and Management Procedures to Encourage RU in Malaysia}

There is no standard qualifying criteria for RU. The defining criteria vary in each country. In Malaysia the title of RU must be awarded by the Ministry of Higher Education (MOHE) upon application by a public university (Ministry of Higher Education Malaysia). There are certain criteria which need to be taken into consideration (Ministry of Higher Education Malaysia).

1) The quantity and quality of researchers within the specific university and this include the number of grants and awards received by the university faculty members and the qualification of the researchers themselves.

2) The quantity and quality of research done is also taken into consideration.

3) The quantity of postgraduates students.

4) The quality of postgraduates students.

5) Innovations owned by the university. This criteria is scrutinised in terms of patent owned by the university, commercialized product, technology know-how licensing and other IPR, copyrights and trademarks.

6) Professional services and gifts.

7) Linkage and collaboration where universities are also being judged on the networking and linkages with overseas universities or institutes.

8) Support facilities that are numbers of Research Centres or Institutes which operates with the university's own budget and have its own postgraduate students.

All these criteria will be judged and universities with results $75 \%$ and above can apply to MOHE to be recognised as RU.

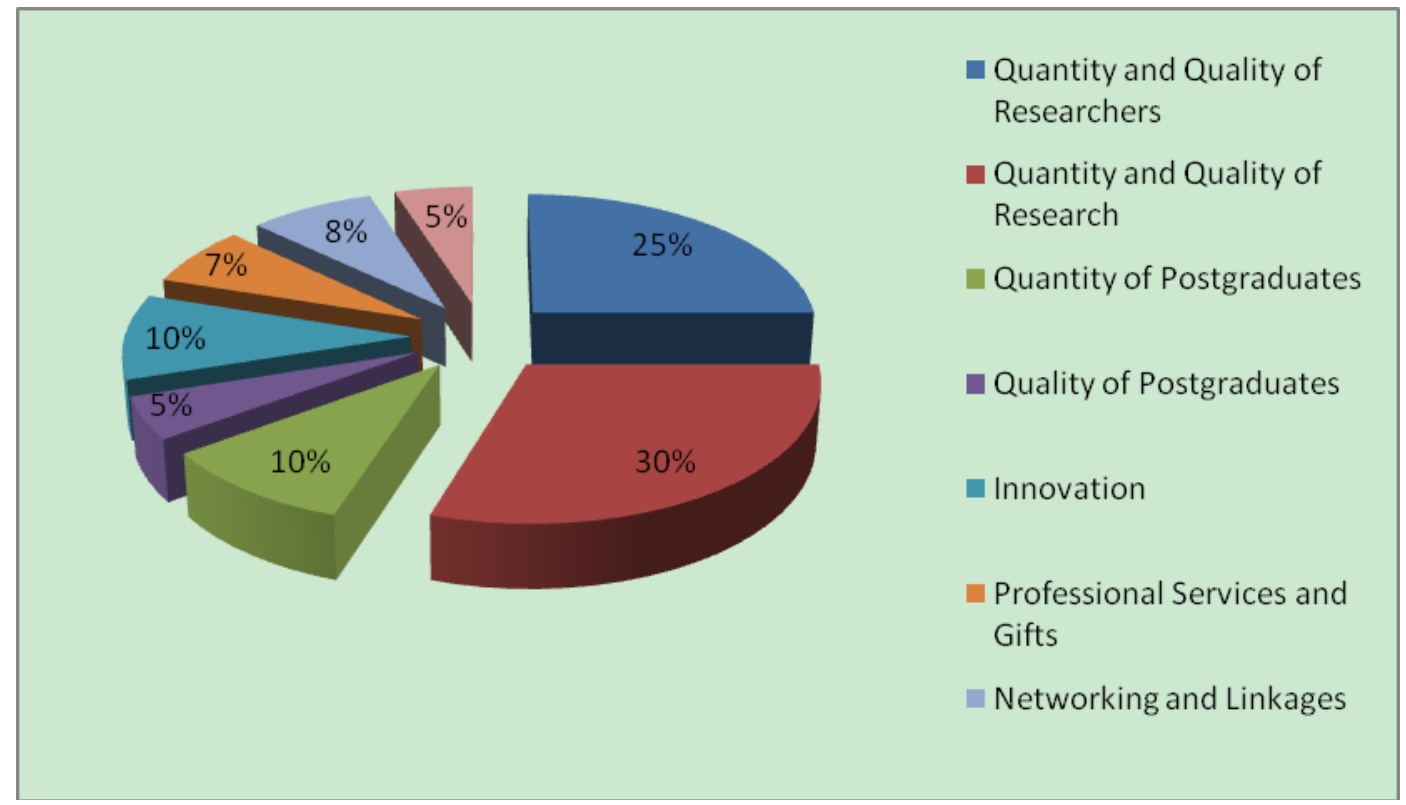

Figure 1. The scorecard for Malaysian research university assessment system

Source: Research University Questionnaires from Ministry of Higher Education Manaysia official website.

It should also be noted that all selected research universities are subjected to audit every 3-5 years (Malaysia-Australia Quality and Excellence in Higher Education Forum, Outcome report 2009). This is from recent amendment to the Malaysian Qualification Agency Act 2007. Under Chapter 4 Part VIII, Section 61 stated that:

"Upon an invitation of the Minister, an application by a higher education provider for self-accreditation status may be made to the Agency on his invitation to do so in such form and manner as may be prescribed."

From the eight criteria of RU laid down by the MOHE it is clear that the purpose of RU is to place Malaysian university among the top and successful universities in the world and also to become a source of knowledge 
generate income for the country. One way to gain this recognition is through The Times Higher Education Supplements (THES) and it should be noted that the most important indicators taken into account in assessing a successful universities are high-quality research, high-quality teaching, high graduate employability and "international outlook" (Times Higher Education). Thus it is believed that policies drafted by the Malaysian government for the Malaysian Research universities do take roots from the requirements considered in the THES.

According to THES, the World University Ranking is a compilation of quantitative indicators and informed opinion. It is not arguable that the task of determining the world universities ranking are indeed more to do with measuring intangible elements it is thus done through assessing the tangible aspects and measurable elements of the university. Therefore THES came out with a scorecard in which they measure performance of the world class university and this is the method used in determining the 2009 World Universities Ranking.

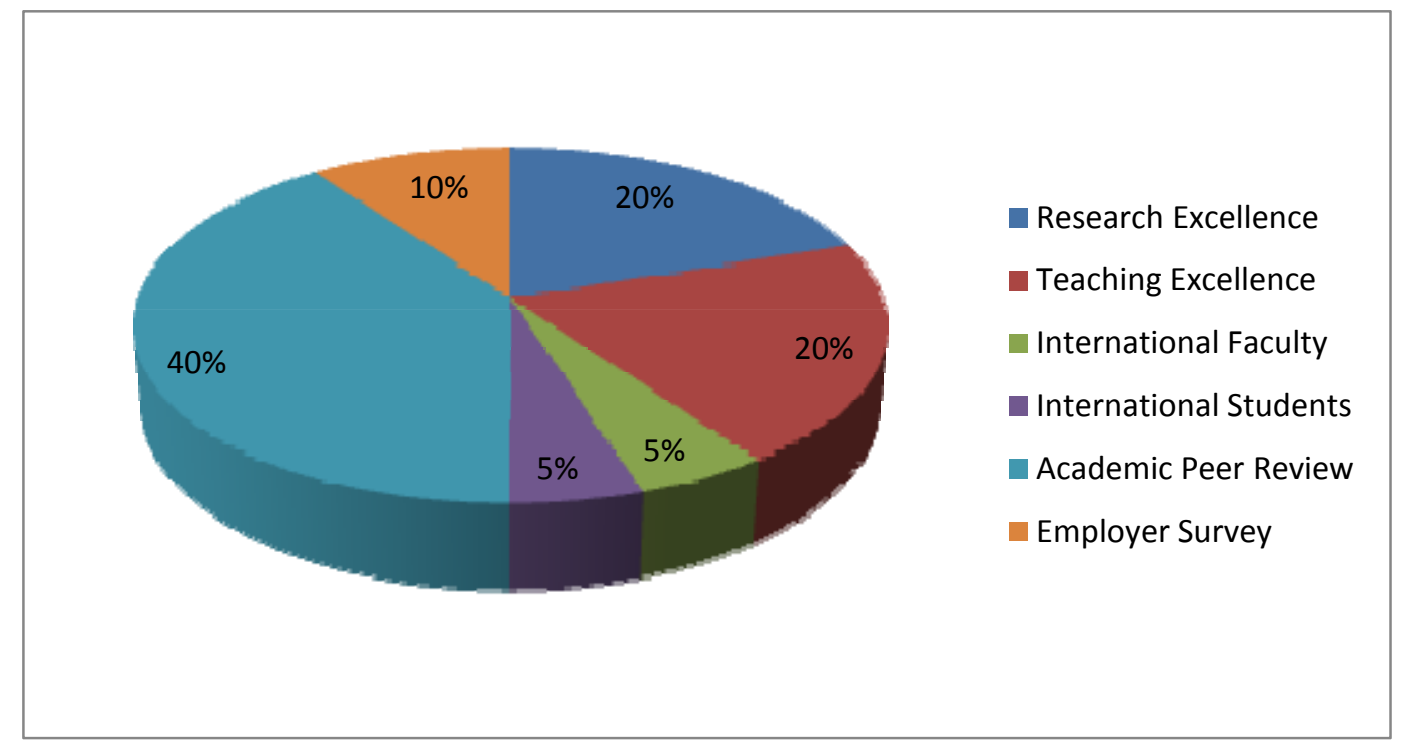

Figure 2. THES scorecard for the 2009 world university rankings

Source: Talking Points: The 2009 World rankings Methodology, www.timeshighereducation.co.uk

It should be noted, there is a new proposed ranking methodology that will be used for the coming 2010 world university rankings. This new methodology gives more attention to the quality of research where $55 \%$ is allocated to the research indicators alone. The scorecard for the new methodology is shown in pie chart below. 

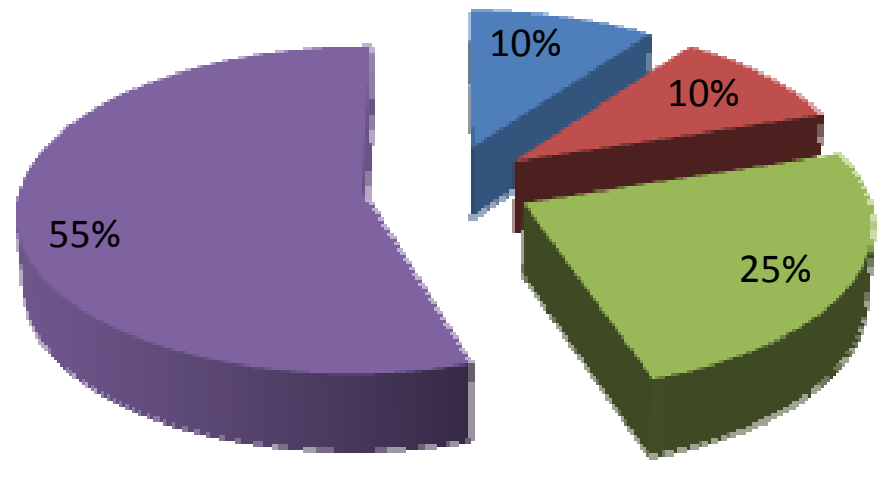

Economic Activit

International Dil

Institutional Indi

Research Indicat

Figure 3. Scorecard for the THES new proposed ranking methodology 2010

Source: The Unveils Broad, Rigorous New Ranking Methodology, www.timeshighereducation.co.uk

The first indicator on Economic activity, a university is measured according to the research income from the industry and scaled against the number of university staffs. While the second indicator, international diversity a university is scaled according to the ratio of international to domestic students and ratio of international to domestic staffs. The third indicator which carries second high percentage for the measurement gives more concern on institutional indicators where few factors are given consideration such as $\mathrm{PhD}$ or undergraduate degrees awarded, institutional income and teaching reputation survey. The last and the biggest indicators is research which gives stress on the citation impact, research income and reputation of the research done. It is believed that the new indicators are more wholesome in measuring the performance of the world university. The fact that economic activity of a university has also been given consideration shows that the entrepreneurial university model has now gain popularity among universities in the world.

Styhre and Lind, defined entrepreneurial university as 'a university which over time demonstrates its capacity to engage in fruitful and mutually rewarding collaborations with industry representatives' (Styhre \& Lind 2009).

While (Etzkowitz ,2003) described the Entrepreneurial University as a university that 'has the ability to generate a focused strategic direction both in formulating academic goals and in translating knowledge produced within the university into economic and social utility.'

Thus from the above definitions it is clear that an entrepreneurial university is a university which focus on teaching, research and utilizing their research outcome into commercialization.

Malaysia which has acknowledged year 2010 as the Malaysian Innovation Year has surely been on the right track. However, comment made by the World Bank Economic Advisor should be given high regard where Dr Shahid Yusof, mentioned that Malaysia is still lacking with innovation hotspot and local universities, research institutes and start ups are still weak (Izwan Idris, 2009). Thus Malaysia might need another five to ten years in order to achieve innovation hotspot. This comment should be acted wisely by the Malaysian government to create policies which will boost up the local research universities performance.

Malaysian government has also put on an enormous effort in promoting innovation and commercialization of research outcome through collaboration of Higher Learning Institutes (HEIs) with private firm (New Year Message of Ministry of Higher Education Malaysia 2010). According to the Minister of Higher Education, Dato' Seri Mohamed Khaled Nordin 2010, Malaysia only commercialized 3.5\% from the total of research outcome whereas in the average of international level is $10 \%$. The Minister has also mentioned that there are few universities which has the potential to become an entrepreneurial university since they manage to get revenue which paid off $30 \%$ or more of the operational expenditure (New Year Message of Minister of Higher Education Malaysia 2010). 
Although commercialization of new invention is still small compared to international level, Malaysian RU still have their astounding achievement in establishing entrepreneurial university. Example can be seen from Universiti Putra Malaysia (UPM) success in commercializing their products where local newspaper stated that they have successfully achieve profit of RM 20.4 million which is the highest compared to other Malaysian public universities (Berita Harian, 2007). Thus it shows that Malaysian RU has what it takes to develop further into the realms of successful research university and later on successful entrepreneurial university provided that Malaysia government and university administration enforced the suitable governing policy according to the background of Malaysian educational culture.

\section{Main Policy and Managerial Implications}

In Malaysia, it should be noted that RU is not a title which is achieved whenever a university started to embark in research activity. However it is awarded by the MOHE through decision by the Evaluator of Research University Committee, to the public university which has achieved a specific criteria and passed performance assessment with 75\% of total mark (Ministry of Higher Education Malaysia 2010).

MOHE has listed down several key performance index (KPI) that must be achieved by each research university and it should be noted that RU audit will take place in April 2010 which is almost 4 years after the establishment of RU in October 2006. The KPIs are:

1) At least $75 \%$ of RU lecturers are $\mathrm{PhD}$ holders

2) 2 papers in national or international refereed and cited journals for each staff every year or cumulative impact factors for the institution of not less than 500 or cumulative citations index of not less than 5000 per year.

3) Research grant for the academic staff at RM 50,000 for each staff every year of which at least $20 \%$ from international sources and $20 \%$ from private sector and research expenditure for each project must not less than $60 \%$ of grant attained every year.

4) There should be 10 appointment of post doctoral per year.

5) Ratio of postgraduate and undergraduate $50: 50$

From the above list it is argued that the requirement of which each and every academic staff has to publish 2 papers in national or international refereed and cited journal every year is impossible to achieve. The argument behind this is that time span to publish a paper in a high impact journal takes more than a year process. A simple analogy can be made from the trend of paper published a high impact journal.

For example Research Policy Journal which has impact factor of 2.655, an article entitled 'A National Systems View of University Entrepreneurialism: Inference from Comparison of the German and US Experience' by Mark Lehrer et al. This paper was received on the $1^{\text {st }}$ August 2007 and it was revised on the $13^{\text {th }}$ November 2008 . This paper was accepted on the $13^{\text {th }}$ November 2008 and available online starting $7^{\text {th }}$ January 2009 . This process has taken more than one year. While in terms of citation of the paper, this will take twice the time of paper publication in a high impact journal.

Besides that it is also difficult to ensure $75 \%$ of $\mathrm{RU}$ lecturers obtain $\mathrm{PhD}$ within 4 years since the time normally required to finish a $\mathrm{PhD}$ degree is 3 years and sometimes it exceed 3 years. With regard to research grants, sometimes it takes more than a year to finish a research and it is quite difficult to judge a RU accomplishment based on the research funding received by each academic staff every year.

Thus from the above discussion it is difficult to measure RU achievement within three or four years. Achievement of RU within 5 to 10 years will be the true yard stick in measuring the success of RU. Looking at all these key performance indexs, it would appear that motivation factor is still very low among the university researchers to invent and innovate whereas those two activities are the main factors that determine successful RU and entrepreneurial university. Therefore more incentives for the researchers are needed to motivate them towards these objectives.

\section{Conclusions}

Malaysian research universities, though they are still in infancy stage hold a very promising future in establishing productive institutions in terms of producing new knowledge and expending it later on. However, certain culture and attitude need to be cultivated and this includes research culture. Research and development (R\&D) activities should be developed properly in order to ensure impressive outcome and not just some non useful invention. Malaysian industries also need to play active role in developing their R\&D and at the same time they should also seek local expertise within local universities in developing their technologies instead of looking at the foreign expertise oversees. 
Besides that a proper Intellectual Property Rights management should be established in order to protect the outcomes of the research done by the Malaysian Research Universities as well as commercializing them in order to accumulate a proper income for the continuance of universities' R\&D.

\section{References}

Abdullah, F. (2009). USM Cipta Alat Elak Barah Otak. Berita Harian.

Atkinson, R. C., \& Blanpied, W. A. (2008). Research Universities: Core of the US Science and Technology System. Technology in Society, 30(1), 30-48. http://dx.doi.org/10.1016/j.techsoc.2007.10.004

Behrens, T. P., \& Gray, D. O. (2001). Unintended Consequences of Cooperative Research: Impact of Industry Sponsorship on Climate for Academic Freedom and other Graduate Student Outcome. Research Policy, 30(2), 179-199. http://dx.doi.org/10.1016/S0048-7333(99)00112-2

Ben-David, J. (1992). Universities and Graduate Education, Research Role of. In Torsten Husen and T. Neville Postlethwaite. The International Encyclopedia of Education Research and Studies (Vol. 9, pp. 5380-5387). New York: Pergamon.

Dooley, L., \& Kirk, D. (2007). University-Industry Collaboration. European Journal of Innovation Management, 10(3), 316-332. http://dx.doi.org/10.1108/14601060710776734

Etzkowitz et al. (2000). The Future of the University and the University of the Future: Evolution of Ivory Tower to Entrepreneurial Paradigm. Research Policy, 29(2), 313-330. http://dx.doi.org/10.1016/S0048-7333(99)00069-4

Etzkowitz, H. (2003). Research Groups as 'Quasi-Firms': the Invention of the Entrepreneurial University. Research Policy, 32(1), 109-121. http://dx.doi.org/10.1016/S0048-7333(02)00009-4

Etzkowitz, H., \& Leydesdorff, L. (2000) The dynamics of innovation: from National Systems and "Mode 2" to a Triple Helix of university-industry-government relation. Research Policy, 29(2), 109-123. http://dx.doi.org/10.1016/S0048-7333(99)00055-4

Fabrizio, K. R. (2007). University Patenting and the Pace of Industrial Innovation. Industrial and Corporate Change, 16(4), 505-534. http://dx.doi.org/10.1093/icc/dtm016

Goldfarb, B. (2008). The Effect of Government Contracting on Academic Research: Does the Source of Funding Affect Scientific Output? Research Policy, 37(1), 41-58. http://dx.doi.org/10.1016/j.respol.2007.07.011

Harian, B. (2007, August 9). UPM Catat Hasil Komersial Terbesar.

JHU. (n. d.). A Brief History of JHU. Retrieved from http://webapps.jhu.edu/jhuniverse/information_about_hopkins/about_jhu/a_brief_history_of_jhu/index.cfm

Kenney, \& Patton (2011). Does inventor ownership encourage university research-derived entrepreneureship? A $\begin{array}{llll}\text { six university } & \text { comparison. Research }\end{array}$ http://dx.doi.org/10.1016/j.respol.2011.05.012

Kenney, M., \& Patton, D. (2009). Reconsidering the Bayh-Dole Act and the Current University Invention Ownership Model. Research Policy, 38(9), 1407-1422. http://dx.doi.org/10.1016/j.respol.2009.07.007

Lee, J., \& Win, H. N. (2004). Technology Transfer Between University Research Centers and Industry in Singapore. Technovation, 24(5), 433-442. http://dx.doi.org/10.1016/S0166-4972(02)00101-3

Lehrer et al. (2009). A National Systems View of University Entrepreneurialism: Inferences from Comparison of the German and US Experience. Research Policy, 38(2), 268-280. http://dx.doi.org/10.1016/j.respol.2008.11.007

Leydesdorff, L., \& Meyer, M. (2007). Triple Helix Indicators of Knowledge -based Innovation Systems: Introduction to the Special Issue. Research Policy, 35(10), 1441-1449. http://dx.doi.org/10.1016/j.respol.2006.09.016

Lu, L. (2008). Creating Knowledge-Based Innovation in China. The Strategic Implication of Triple Helix Model. Journal of Technology Management in China, 3(3), 249-263. http://dx.doi.org/10.1108/17468770810916168

McCormick, \& Zhao. (2005). Rethinking and Reframing The Carnegie Classification. Change, 51-57. http://dx.doi.org/10.3200/CHNG.37.5.51-57

Morphew, C. (2003). Research Universities. In J. W. Guthrie (Ed.), Encyclopedia of Education (2nd ed., pp. 
2041-2043). USA: Gale.

New Straits Times. (2008, December 31). An Entrepreneurial Dream.

New Straits Times. (2009, March 1). Proton and UTM tie-up.

Ramasamy et.al. (2004). Malaysia's Leap into the Future: an Evaluation of Multimedia Super Corridor. Technovation, 4(11), 871-883. http://dx.doi.org/10.1016/S0166-4972(03)00049-X

Rappert et al. (1999). Making Sense of Diversity and Reluctance: Academic- Industrial Relations and Intellectual Property. Research Policy, 28(8), 873-890. http://dx.doi.org/10.1016/S0048-7333(99)00028-1

Rasmussen, E. (2008). Government Instruments to Support the Commercialization of University Research: Lessons from Canada. Technovation, 28(8), 506-517. http://dx.doi.org/10.1016/j.technovation.2007.12.002

Rosell, C., \& Agrawal, A. (2009). Have University Knowledge Flows Narrowed?: Evidence From Patent Data. Research Policy, 38(1), 1-13. http://dx.doi.org/10.1016/j.respol.2008.07.014

Shapira et al. (2006). Knowledge economy measurement: Methods, results and insights from the Malaysian $\begin{array}{lllll}\text { Knowledge Content Study. Research } & \text { Policy, }\end{array}$ http://dx.doi.org/10.1016/j.respol.2006.09.015

Shils, E. (1992). Universities: Since 1900. In B. R. Clark, \& G. R. Neave (Eds.), The Encyclopedia of Higher Education (Vol. 2, pp. 1259-1275). New York: Pergamon.

Steffensen et al. (2000). Spin-offs from Research Centers at a Research University. Journal of Business Venturing, 15(1), 93-111. http://dx.doi.org/10.1016/S0883-9026(98)00006-8

Stephen. (2010). Asian Initiatives on Bayh- Dole, With Special Reference to India: How do we make it more “Asian?". 10 Chi.-Kent J. Intell. Prop, 44.

Styhre, A., \& Lind, F. (2009). The Softening Bureaucracy: Accomodating New Research Opportunities in the Entrepreneurial University. Scandinavian Journal of management, Article in Press.

Thursby, J. G., \& Thursby, M. C. (2007). University Licensing. Oxford Review of Economic Policy, 23(4), 620-639. http://dx.doi.org/10.1093/oxrep/grm031

Tidd, J., \& Brocklehurst, M. (1999). Routes to Technological Learning and Development: An Assessment of Malaysia's Innovation Policy and Performance. Technological Forecasting and Social Change, 62(3), 239-257. http://dx.doi.org/10.1016/S0040-1625(99)00047-5

Tuffs, A. (2006). Giving German Universities a Boosts. Cell, 126(4), 635-636. http://dx.doi.org/10.1016/j.cell.2006.08.010

Wong et al. (2007). Towards an "Entrepreneurial University" Model to Support Knowledge-Based Economic Development: The case of the National University of Singapore. World Development, 35(6), 941-958. http://dx.doi.org/10.1016/j.worlddev.2006.05.007

Zhou, C. (2008). Emergence of Entrepreneurial University in Evolution of Triple Helix, The Case of Northeastern University in China. Journal of Technology Management in China, 3(1), 109-126. http://dx.doi.org/10.1108/17468770810851539 